\title{
Hubungan Kualifikasi Akademik dan Kinerja Guru dengan Hasil Belajar Siswa
}

\author{
Zuria Lupita1, K.A. Rahman $^{2}$, Urip Sulistiyo ${ }^{3}$ \\ ${ }^{123}$ Pascasarjana Universitas Jambi, Jalan Raden Mataher No 16 Kota Jambi, Indonesia
}

Email: zuria_lupita93@yahoo.com

\begin{abstract}
ABSTRAK
Penelitian ini bertujuan untuk mengetahui gambaran kualifikasi akademik dan kinerja guru dengan hasil belajar siswa di Sekolah Menengah Atas Negeri di Kota Jambi tahun 2019. Penelitian ini merupakan jenis penelitian kuantitatif dengan desain korelasional karena peneliti ingin mengetahui tingkat hubungan antara dua variabel atau lebih. Instrumen pengumpulan data melalui penyebaran angket. Uji validitas yang digunakan yaitu uji validitas instrumen dan reliabilitas. Berdasarkan hasil penelitian dan pengujian hipotesis dari 30 responden guru dan 9 hasil nilai mata pelajaran yang termasuk dalam UNBK diperoleh 96,7\% responden memiliki kualifikasi akademik Berkualifikasi, kinerja guru Sangat Baik yaitu 96,7 \%, dengan hasil belajar termasuk dalam kategori Cukup yaitu 44,44\% dan 56,6\% memiliki hasil belajar siswa Kurang baik pada Sekolah Menengah Atas Negeri di Kota Jambi Tahun Ajaran 2018-2019. Hasil penelitian menunjukkan bahwa tidak terdapat hubungan yang signifikan antara kualifikasi akademik dan kinerja guru dengan hasil belajar siswa di Sekolah Menengah Atas Negeri di Kota Jambi Tahun Ajaran 2018-2019.
\end{abstract}

Kata Kunci: Kualifikasi akademik, kinerja guru, hasil belajar siswa.

\section{ABSTRACT}

This study aims to learn about academic qualifications and teacher performance with student learning outcomes at State Senior High Schools in the City of Jambi. This research is a type of quantitative research with a correlational design because researchers want to know the research relationship between two or more variables. Data collection instruments through questionnaires. The validity test used is the instrument validity and reliability test. Based on the results of research and hypothesis testing of 30 teacher respondents and 9 results of assessment of subjects included in UNBK obtained $96.7 \%$ of respondents have Qualified academic qualifications, the teacher's performance is very good at 96.7\%, with learning outcomes included in the Fair category with 44, 44\% and 56.6\% had poor student learning outcomes at the State Senior High School in Jambi City Academic Year 2018-2019. The results showed that there was no significant relationship between academic qualifications and teacher performance with student learning outcomes in State Senior High Schools in Jambi City 2018-2019 Academic Year.

Keywords: Academic qualifications, teacher performance, student learning outcomes.

(C) 2020 Zuria Lupita

Pedagogika.fip@ung.ac.id P-ISSN: 2086-4469Ｅ-ISSN: 2716-0580 


\section{PENDAHULUAN}

Pendidikan adalah usaha sadar dan terencana untuk mewujudkan suasana belajar dan proses pembelajaran agar peserta didik secara aktif mengembangkan potensi dirinya untuk memiliki kekuatan spiritual keagamaan, pengendalian diri, kepribadian, kecerdasan, akhlak mulia, serta keterampilan yang diperlukan dirinya, masyarakat, bangsa dan negara (Undang-Undang Republik Indonesia Nomor 20 Tahun 2003) tentang Sistem Pendidikan Nasional.

Kualitas sumber daya manusia Indonesia tidak terlepas dari lembaga pendidikan, tenaga kependidikan guru yang merupakan pendidik yang berperan secara aktif dalam hal mengembangkan potensi yang terdapat dalam diri peserta didik. Tenaga kependidikan merupakan suatu komponen yang penting dalam penyelenggaraan pendidikan, yang bertugas menyelenggarakan kegiatan mengajar, melatih, meneliti, mengembangkan, mengelola dan atau memberikan pelayanan teknis dalam bidang pendidikan. Sebagaimana yang diamanatkan Pasal 39 Ayat 2 menyatakan bahwa pendidik merupakan tenaga profesional yang bertugas merencanakan dan melaksanakan proses pembelajaran, menilai hasil pembelajaran, melakukan pembimbingan dan pelatihan, serta melakukan penelitian dan pengabdian kepada masyarakat, terutama bagi pendidik pada perguruan tinggi.

Pernyataan tersebut sejalan dengan pendapat Hidayat dan Machali (2010:44), bahwa pendidik dalam sistem pendidikan Pedagogika.fip@ung.ac.id $\quad$ P-ISSN: 2086-4469 nasional adalah tenaga kependidikan yang berkualifikasi sebagai guru, dosen, konselor, pamong belajar, tutor, instruktor dan fasilitator. Pendidik pada sekolah dasar hingga menengah adalah guru. Guru adalah pendidik profesional dengan tugas utamanya mendidik, mengajar, membimbing, mengarahkan, melatih, menilai, dan mengevaluasi. Hal tersebut bertujuan untuk melaksanakan dan mewujudkan tujuan pendidikan nasional yaitu mengembangkan potensi peserta didik agar menjadi manusia yang beriman dan bertakwa kepada Tuhan Yang Maha Esa, berakhlak mulia, sehat, berilmu, cakap, kreatif, mandiri serta memiliki sifat demokratis dan bertanggung jawab untuk menjadi warga Negara.

Menurut Hamalik (2010, 3-4), tujuan pendidikan adalah seperangkat hasil pendidikan yang tercapai oleh peserta didik setelah diselengarakannya kegiatan pendidikan. Seluruh kegiatan pendidikan, yakni bimbingan pengajaran, dan latihan yang diarahkan untuk mencapai tujuan pendidikan. Dalam konteks ini, tujuan pendidikan merupakan suatu komponen sistem pendidikan yang menempati kedudukan dan fungsi sentral. Itu sebabnya setiap tenaga kependidikan perlu memahami dengan baik tujuan pendidikan, supaya berupaya melaksanakan tugas dan fungsinya untuk mencapai tujuan pendidikan yang telah ditentukan.

Tenaga pendidik tugas utamanya adalah mengajar, karena tugas utamanya mengajar, maka harus memiliki wewenang mengajar berdasarkan kualifikasi sebagai

E-ISSN: 2716-0580 
tenaga pengajar. Oleh karena itu sebagai tenaga pengajar, setiap guru harus memiliki kemampuan profesional dalam bidang pembelajaran. Dalam dunia pendidikan dikenal istilah kegiatan belajar mengajar. Kegiatan belajar mengajar merupakan serangkaian kegiatan guru dan siswa atas dasar hubungan timbal balik yang berlangsung dalam situasi edukatif untuk mencapai tujuan tertentu. Seorang guru dikatakan sebagai pemegang peran utama, karena guru yang bertanggung jawab untuk memimpin dan mengorganisasikan lingkungan yang berhubungan dengan siswa dan bahan pelajaran. Sehingga menimbulkan proses belajar pada siswa. Oleh karena itu salah satu faktor berhasil tidaknya pendidikan pada siswa sangat tergantung pada tanggung jawab seorang guru. Karena pentingnya peran guru, maka seorang guru harus memiliki kualifikasi pendidikan yang sesuai dengan mata pelajaran yang diajar dan kinerja yang baik agar mampu menciptakan kegiatan belajar mengajar sehingga hasil belajar berada pada tingkat yang optimal (Hamalik, 2010:9).

Berdasarkan Peraturan Menteri Pendidikan Nasional (Permendiknas) Nomor 16 Tahun 2007 tentang standar kualifikasi akademik dan kompetensi guru bahwa dalam rangka pelaksanaan Pasal 28 Ayat 5 Peraturan Pemerintah (PP) Nomor 19 Tahun 2005 tentang Standar Nasional Pendidikan (SNP), perlu menetapkan Peraturan Menteri Pendidikan Nasional (Permendiknas) tentang standar kualifikasi akademik dan kompetensi guru, pada peraturan menteri Pasal 1 ayat 1 bahwa standar nasional pendidikan adalah kriteria minimal tentang sistem pendidikan di seluruh wilayah hukum Negara Kesatuan Republik Indonesia. Artinya setiap guru wajib memenuhi standar kualifikasi akademik dan kompetensi guru yang berlaku secara nasional.

Guru pada Sekolah Menengah Atas, Madrasah Aliyah atau bentuk lain yang sederajat harus memiliki kualifikasi akademik pendidikan minimum diploma empat (D-IV) atau sarjana (Strata I) program studi yang sesuai dengan mata pelajaran yang diajarkan/diampu. Hal tersebut berdasarkan Peraturan Pemerintah Nomor 19 Tahun 2005 Pasal 29 Ayat 4. Sedangkan kompetensi guru meliputi kompetensi pedagogik, kompetensi kepribadian, kompetensi profesional dan kompetensi sosial yaitu pada pasal 28 Ayat 3. UndangUndang Nomor 14 Tahun 2005 tentang guru dan dosen pada pasal 8 bahwa "seorang pendidik (guru) harus memiliki kualifikasi, kompetensi, sertifikat pendidik, sehat jasmani dan rohani, serta memiliki kemampuan untuk mewujudkan tujuan pendidikan nasional".

Selain itu untuk melihat kualitas guru dalam proses pembelajaran perlu suatu proses penilaian kinerja guru. Menurut Dermawati (2013:5), pelaksanaan penilaian kinerja guru dimaksudkan bukan untuk menyulitkan guru, melainkan untuk mewujudkan guru yang profesional. Untuk meyakinkan bahwa setiap guru adalah seorang profesional pada semua bidangnya, maka penilaian kinerja guru harus dilakukan terhadap guru setiap satuan pendidikan formal yang diselenggarakan oleh 
pemerintah daerah dan masyarakat. Hal ini seperti yang diamanatkan dalam Peraturan Menteri Pendayagunaan Aparatur Negara dan Reformasi Birokrasi (PERMENPAN RB) Nomor 16 Tahun 2009 tentang jabatan fungsional guru dan angka kreditnya.

Untuk mewujudkan sikap profesionalitas guru, maka diaturlah ketentuan dalam Undang-Undang Nomor 14 Tahun 2005 tentang guru dan dosen pada Pasal 8 menyebutkan bahwa guru wajib memiliki kualifikasi akademik, kompetensi, sertifikat pendidik, sehat jasmani dan rohani, serta memiliki kemampuan untuk mewujudkan tujuan pendidikan nasional. Semua itu tidak luput dari kinerja guru itu sendiri, istilah kinerja berasal dari kata job performance/actual performance yang dapat diartikan sebagai prestasi kerja atau prestasi sesungguhnya yang dicapai oleh seseorang. Guru dapat mencapai kinerja yang maksimal jika guru mau berusaha untuk mengembangkan seluruh kompetensi yang dimilikinya dan juga memanfaatkan serta menciptakan situasi yang ada di lingkungan sekolah sesuai dengan aturan yang berlaku dalam proses pengajaran, unsur proses belajar memegang peran vital. Mengajar adalah proses membimbing kegiatan belajar, bahwa kegiatan mengajar hanya bermakna apabila terjadi kegiatan belajar murid (Hamalik, 2003:27).

Berdasarkan pengumpulan data awal yang dilakukan oleh peneliti dilapangan penilaian kinerja guru tidak dilakukan secara rutin dan berkesinambungan. Hal tersebut dilakukan sudah beberapa tahun sebelumnya. Jika minimnya tenaga pengajar suatu lembaga pendidikan, maka dapat memberi kesempatan seorang guru untuk mengajar tidak sesuai dengan keahliannya. Sehingga yang menjadi imbasnya adalah siswa sebagai anak didik tidak mendapatkan hasil pembelajaran maksimal. Padahal siswa adalah sasaran pendidikan yang dibentuk melalui bimbingan, keteladanan, bantuan, latihan, pengetahuan yang maksimal, kecakapan, keterampilan, nilai, sikap yang baik dari seorang guru. Maka hanya dengan guru profesional dan kinerja yang baik hal tersebut dapat terwujud secara utuh, sehingga dapat menciptakan kondisi yang menimbulkan kesadaran dan keseriusan dalam proses belajar mengajar. Berdasarkan SK mengajar yang telah dilihat oleh peneliti pada beberapa sekolah di Kota Jambi, guru telah menyandang gelar Strata I (S1) bahkan Strata II (S2) yang tujuan utamanya adalah untuk meningkatkan profesionalitas kualifikasi kinerja dalam memberikan ilmu kepada siswanya. Dengan demikian, apa yang disampaikan guru akan berpengaruh terhadap hasil belajar siswa. Sebaliknya, jika hal tersebut tidak terealisasi dengan baik, maka akan berakibat ketidakpuasan siswa dalam proses kegiatan belajar mengajar.

\section{METODE PENELITIAN}

Penelitian ini merupakan penelitian kuantitatif dengan desain korelasional. Menurut Arikunto (2013:4), penelitian korelasional adalah penelitian yang dilakukan peneliti untuk mengetahui tingkat hubungan antara dua variabel atau lebih, tanpa melakukan perubahan, tambahan atau manipulasi terhadap data yang sudah ada.

\section{E-ISSN: 2716-0580}


Pengambilan sampel menggunakan teknik probability sampling.

Probability sampling adalah teknik pengambilan sampel yang memberikan peluang yang sama bagi setiap anggota populasi untuk dipilih menjadi anggota sampel. Digunakan teknik cluster sampling untuk menentukan sampel bila objek yang diteliti sangat luas, untuk menentukan mana yang dijadikan sumber data, maka pengambilan sampelnya berdasarkan daerah populasi yang telah ditetapkan (Sugiyono (2009:82). Kualifikasi akademik dan kinerja guru Sekolah Menengah Atas Negeri di Kota Jambi variabel (X) digunakan skala pengukuran yaitu skala likert. Menurut Sugiyono (2010:134), skala likert digunakan untuk mengukur sikap, pendapat, dan persepsi seseorang atau sekolompok orang tentang fenomena sosial. Dengan skala likert variabel yang diukur dapat dijabarkan menjadi indikator variabel. Sedangkan untuk mengetahui hasil belajar siswa variabel (Y) adalah dengan melihat hasil nilai rata-rata ujian nasional berbasis komputer (UNBK) pada tahun ajaran 2018-2019 berupa dokumen arsip sekolah.

\section{HASIL DAN PEMBAHASAN}

Berdasarkan hasil analisis data diketahui bahwa dari total 9 mata pelajaran yang termasuk dalam UNBK, terdiri 5 mata pelajaran $(56,6 \%)$ termasuk kategori hasil belajar siswa Kurang dan 4 mata pelajaran $(44,4 \%)$ termasuk kategori hasil belajar siswa Cukup. Hal tesebut dapat dilihat pada Tabel 1.

\section{Tabel 1. Hasil belajar siswa}

\begin{tabular}{cccc}
\hline No & Hasil Belajar & Jumlah & \% \\
\hline 1. & Hasil Belajar Siswa Kurang & 5 & 56,6 \\
2. & Hasil Belajar Siswa Cukup & 4 & 44,4 \\
& Total & 9 & 100 \\
\hline
\end{tabular}

Tidak Berkualifikasi dan sebanyak 29 orang

Selanjutnya diketahui bahwa dari 30 responden dalam penelitian ini sebanyak 1 orang $(3,3 \%)$ responden temasuk kategori
$(96,7 \%)$ responden termasuk kategori Berkualifikasi. Dapat dilihat pada Tabel 2.

Tabel 2. Kualifikasi akademik guru

\begin{tabular}{cccc}
\hline No & Kualifikasi Akademik Guru & Jumlah & \% \\
\hline 1. & Tidak Berkualifikasi & 1 & 3.3 \\
2. & Berkualifikasi & 29 & 96.7 \\
& Total & 30 & 100 \\
\hline
\end{tabular}

Pedagogika.fip@ung.ac.id $\quad$ P-ISSN: 2086-4469 E-ISSN: 2716-0580 
Lebih lanjut diketahui bahwa dari 30 orang responden sebanyak 1 orang $(3,3 \%)$ responden termasuk kategori kinerja guru Tidak Baik dan sebanyak 29 orang $(96,7 \%)$ responden termasuk kedalam kategori kinerja guru Sangat Baik. Dapat dilihat pada tabel 3.

Tabel 3. Kinerja guru

\begin{tabular}{cccc}
\hline No & Kinerja Guru & Jumlah & \% \\
\hline 1. & Tidak Baik & 1 & 3.3 \\
2. & Sangat Baik & 29 & 96.7 \\
& Total & 30 & 100 \\
\hline
\end{tabular}

\section{Hasil Analisis Bivariat}

Hasil analisis hubungan kualifikasi akademik guru dengan hasil belajar siswa pada SMA
Negeri di Kota Jambi tahun ajaran 20182019 dapat dilihat pada Tabel 4:

Tabel 4. Analisis hubungan kualifikasi akademik guru dengan hasil belajar

\begin{tabular}{|c|c|c|c|c|c|c|c|}
\hline \multirow{3}{*}{ No } & \multirow{3}{*}{$\begin{array}{l}\text { Kualifikasi } \\
\text { Akademik } \\
\text { Guru }\end{array}$} & \multicolumn{4}{|c|}{$\begin{array}{c}\text { Hasil Belajar Siswa Pada SMA Negeri di } \\
\text { Kota Jambi }\end{array}$} & \multirow{2}{*}{\multicolumn{2}{|c|}{ Juml }} \\
\hline & & \multicolumn{2}{|c|}{ Kurang Baik } & \multicolumn{2}{|r|}{ Cukup } & & \\
\hline & & Jumlah & $\%$ & Jumlah & $\%$ & Jumlah & $\%$ \\
\hline \multirow{3}{*}{2} & $\begin{array}{l}\text { Tidak } \\
\text { Berkualifikasi }\end{array}$ & 1 & $\begin{array}{l}11 \\
11\end{array}$ & 0 & 0 & 1 & \multirow{3}{*}{0,1000} \\
\hline & Berkualifikasi & 4 & $\begin{array}{c}44 \\
44\end{array}$ & 4 & 44,44 & 8 & \\
\hline & Jumlah & 5 & $\begin{array}{c}55 \\
6\end{array}$ & 4 & 44,4 & 9 & \\
\hline \multicolumn{5}{|c|}{$\begin{array}{l}\text { Berdasarkan Tabel di atas diketahui } \\
\text { bahwa dari total } 9 \text { mata pelajaran, responden } \\
\text { yang dikategorikan Tidak Berkualifikasi } \\
\text { berjumlah } 1(11,11 \%) \text { responden dengan } \\
\text { hasil belajar siswa Kurang Baik, sebanyak } 4\end{array}$} & \multicolumn{3}{|c|}{$\begin{array}{l}\text { statistik diperoleh nilai p-value }=0,1000 \\
\text { maka } \mathrm{H}_{0} \text { diterima dan dapat disimpulkan } \\
\text { tidak terdapat hubungan yang signifikan } \\
\text { antara kualifikasi akademik guru dengan } \\
\text { hasil belajar siswa pada SMA Negeri di Kota } \\
\text { Jambi Tahun ajaran 2018-2019. }\end{array}$} \\
\hline \multicolumn{5}{|c|}{$\begin{array}{l}(44,44 \%) \text { responden termasuk dalam } \\
\text { kategori Berkualifikasi dengan hasil belajar } \\
\text { Kurang Baik, sebanyak } 4(44,44) \text { responden }\end{array}$} & \multicolumn{3}{|c|}{$\begin{array}{l}\text { Hubungan kinerja guru dengan hasil } \\
\text { belajar siswa pada SMA Negeri di Kota } \\
\text { Jambi tahun ajaran 2018-2019 }\end{array}$} \\
\hline
\end{tabular}

termasuk dalam kategori Berkualifikasi dengan hasil belajar siswa Cukup. Hasil uji 
Hasil analisis hubungan kualifikasi dilihat pada Tabel 5. akademik guru dengan kinerja guru dapat

Tabel 5. Analisis hubungan kualifikasi akademik guru dengan kinerja guru

\begin{tabular}{|c|c|c|c|c|c|c|c|c|}
\hline \multirow{3}{*}{ No } & \multirow{3}{*}{$\begin{array}{l}\text { Kinerja } \\
\text { Guru }\end{array}$} & \multicolumn{4}{|c|}{$\begin{array}{c}\text { Hasil Belajar Siswa pada SMA } \\
\text { Negeri di Kota Jambi }\end{array}$} & \multirow{2}{*}{\multicolumn{2}{|c|}{ Jumlah }} & \multirow{3}{*}{ P-Value } \\
\hline & & \multicolumn{2}{|c|}{ Kurang Baik } & \multicolumn{2}{|c|}{ Cukup } & & & \\
\hline & & Jumlah & $\%$ & Jumlah & $\%$ & Jumlah & $\%$ & \\
\hline 1 & Tidak Baik & 1 & 11,11 & 0 & 0 & 1 & 100 & \\
\hline 2 & Sangat Baik & 4 & 44,44 & 4 & 44,44 & 8 & 100 & 0.1000 \\
\hline & Jumlah & & 5 & 55,6 & 4 & 44,4 & 9 & \\
\hline
\end{tabular}

Berdasarkan Tabel di atas diketahui bahwa dari 9 mata pelajaran responden yang memiliki kinerja guru Tidak Baik sebanyak 1 $(11,11 \%)$ responden hasil belajar siswa Kurang Baik, sebanyak 4 (44,44 \%) memiliki kinerja guru Sangat Baik dengan hasil belajar siswa Kurang Baik, sebanyak 4 $(44,44)$ responden kinerja guru Sangat Baik dengan hasil belajar siswa Cukup. Hasil uji statistik diperoleh nilai $p$-value $=0,1000$ maka $\mathrm{H}_{0}$ diterima dan dapat disimpulkan tidak terdapat hubungan yang signifikan antara kinerja guru dengan hasil belajar siswa pada Sekolah Mengengah Atas Negeri di Kota Jambi Tahun Ajaran 2018-2019.

Hubungan Kualifikasi akademik guru dengan Kinerja guru pada SMA Negeri di Kota Jambi tahun ajaran 2018-2019

Hasil analisis hubungan kualifikasi akademik guru dengan kinerja guru dapat dilihat pada Tabel 6.

Tabel 6. Analisis hubungan kualifikasi akademik guru dengan kinerja guru

\begin{tabular}{|c|c|c|c|c|c|c|c|c|}
\hline \multirow{3}{*}{ No } & \multirow{3}{*}{$\begin{array}{c}\text { Kualifikasi } \\
\text { Akademik } \\
\text { Guru }\end{array}$} & \multicolumn{4}{|c|}{$\begin{array}{c}\text { Kinerja Guru SMA Negeri di } \\
\text { Kota Jambi }\end{array}$} & \multirow{2}{*}{\multicolumn{2}{|c|}{ Jumlah }} & \multirow{3}{*}{ P-Value } \\
\hline & & \multicolumn{2}{|c|}{ Tidak Baik } & \multicolumn{2}{|c|}{ Sangat Baik } & & & \\
\hline & & Jumlah & $\%$ & Jumlah & $\%$ & Jumlah & $\%$ & \\
\hline 1 & $\begin{array}{c}\text { Tidak } \\
\text { Berkualifikasi }\end{array}$ & 1 & 3,3 & 0 & 0 & 1 & 100 & 0,008 \\
\hline \multirow[t]{2}{*}{2} & Berkualifikasi & 0 & 0 & 29 & 96,7 & 29 & 100 & \\
\hline & Jumlah & 1 & 3,3 & 29 & 96,7 & 30 & 100 & \\
\hline
\end{tabular}

Berdasarkan Tabel di atas diketahui bahwa dari total 30 responden yang dikategorikan Tidak Berkualifikasi berjumlah $1(3,3 \%)$ responden dengan kinerja guru Tidak Baik, sebanyak 29 $(96,7 \%)$ responden termasuk dalam kategori Berkualifikasi dengan Kinerja Guru Sangat
Baik. Hasil uji statistik diperoleh nilai $p$ value $=0,008$ maka Ha diterima dan dapat disimpulkan terdapat hubungan yang signifikan antara kualifikasi akademik guru dengan kinerja guru pada SMA Negeri di Kota Jambi Tahun ajaran 2018-2019. 
Hasil correlations kualifikasi akademik dan kinerja guru dengan hasil belajar siswa pada SMA Negeri di Kota Jambi tahun ajaran 2018-2019
Hasil analisis hubungan kualifikasi akademik guru dengan hasil belajar siswa dapat dilihat pada Tabel $7 \mathrm{t}$.

Tabel 7. Korelasi kualifikasi akademik dan kinerja guru dengan hasil belajar siswa

\begin{tabular}{|c|c|c|c|c|}
\hline & & $\begin{array}{c}\text { Y Hasil } \\
\text { Belajar } \\
\text { Siswa }\end{array}$ & $\begin{array}{c}\text { X1 Kualifikasi } \\
\text { Pendidikan Guru }\end{array}$ & X2 Kinerja Guru \\
\hline $\mathbf{Y}$ & Pearson correlation & 1 & .316 & .316 \\
\hline \multirow[t]{2}{*}{ Hasil belajar } & Sig. (2-tailed) & & .407 & .407 \\
\hline & $\mathrm{N}$ & 9 & 9 & 9 \\
\hline X1 & Pearson correlation & .316 & 1 & $1.000^{* *}$ \\
\hline Kualifikasi & Sig. (2-tailed) & .407 & & .000 \\
\hline Pendidikan Guru & $\mathrm{N}$ & 9 & 30 & 30 \\
\hline $\mathbf{X} 2$ & Pearson correlation & .316 & $1.000^{* *}$ & 1 \\
\hline \multirow[t]{2}{*}{ Kinerja Guru } & Sig. (2-tailed) & .407 & .000 & \\
\hline & $\mathrm{N}$ & 9 & 30 & 30 \\
\hline
\end{tabular}

Berdasarkan Tabel 7 di atas diketahui bahwa dari 9 mata pelajaran dan 30 responden diketahui hasil uji statistik diperoleh nilai $p$-value $=0,316$ lebih besar dari 0.05 maka $\mathrm{H}_{0}$ diterima dan dapat disimpulkan bahwa tidak terdapat hubungan yang signifikan antara kualifikasi akademik dan kinerja guru dengan hasil belajar siswa pada SMA Negeri di Kota Jambi tahun ajaran 2018-2019.

Tabel 8. Summary

\begin{tabular}{|c|c|c|c|c|c|c|c|c|c|}
\hline \multirow[t]{2}{*}{ Model } & \multirow[t]{2}{*}{$\mathbf{R}$} & \multirow{2}{*}{$\begin{array}{c}\text { R } \\
\text { Square }\end{array}$} & \multirow{2}{*}{$\begin{array}{c}\text { Adjusted } \\
\text { R } \\
\text { Square }\end{array}$} & \multirow{2}{*}{$\begin{array}{c}\text { Std. } \\
\text { Error of } \\
\text { the } \\
\text { Estimate }\end{array}$} & \multicolumn{5}{|c|}{ Change Statistics } \\
\hline & & & & & $\begin{array}{c}\text { R } \\
\text { Square } \\
\text { Change }\end{array}$ & $\begin{array}{c}\mathrm{F} \\
\text { Change }\end{array}$ & df1 & df2 & $\begin{array}{c}\text { Sig. F } \\
\text { Change }\end{array}$ \\
\hline 1 & $.316^{\mathrm{a}}$ & .100 & -.029 & .535 & .100 & .778 & 1 & 7 & .407 \\
\hline
\end{tabular}

a. Predictors: (constant), Kualifikasi pendidikan

Pembahasan

Belajar siswa

Berdasarkan hasil penelitian diketahui bahwa responden yang memiliki hasil belajar Kurang $5(56,6 \%)$ mata pelajaran dan kategori Cukup ada $4(44,4 \%)$ mata pelajaran, artinya sebagian besar sekolah memiliki nilai Ujian Nasional Berbasis
Komputer yang termasuk kategori Kurang. Hal ini terjadi mungkin dikarenakan kurikulum di Indonesia selalu mengalami perubahan. Disisi lain, setiap daerah memiliki kemampuan yang berbeda mulai dari sarana prasarana hingga kualitas guru dan siswa juga harus dapat mengikuti perubahan tersebut. Peneliti menyarankan 
salah satu upaya agar dapat meningkatkan hasil belajar siswa yaitu dengan melengkapi sarana dan prasarana pendukung saat melakukan pengajaran.

\section{Kualifikasi guru}

Berdasarkan hasil penelitian diketahui bahwa responden guru yang Tidak Berkualifikasi $1(3,3 \%)$ dan sebagian besar guru Berkualifikasi 29 (96,7\%), artinya hampir semua guru jenjang Sekolah Menengah Atas di Kota Jambi Berkualifikasi. Berdasarkan Peraturan Menteri Pendidikan Nasional (Permendiknas) Nomor 16 Tahun 2007 tentang Standar Kualifikasi Akademik dan Kompetensi Guru bahwa dalam rangka pelaksanaan Pasal 29 Ayat 4 Peraturan Pemerintah (PP) Nomor 19 Tahun 2005 tentang Standar Nasional Pendidikan (SNP) dimana guru harus memiliki kualifikasi pendidikan $\mathrm{S} 1$ sesuai dengan mata pelajaran yang di ajar. Peneliti menyarankan agar guru tidak hanya cukup di S1 saja. Guru diharapkan dapat melanjutkan pendidikan ke jenjang lebih tinggi lagi karena pendidikan akan terus berkembang jangan sampai guru tidak dapat mengikuti perkembangan pendidikan tersebut. Selain itu, siswa juga akan berpikir lebih kritis lagi maka dari itu guru dituntut untuk selalu menambah wawasan pendidikannya.

\section{Kinerja guru}

Berdasarkan hasil penelitian diketahui bahwa responden kinerja guru Tidak Baik 1 $(3,3 \%)$ dan sebagian besar memiliki kinerja guru Sangat Baik 29 (96,7\%), artinya sebagian besar guru jenjang Sekolah Mengengah Atas di Kota Jambi memiliki kinerja guru Sangat Baik. Kinerja guru dapat ditunjukkan berdasarkan kompetensi yang dipersyaratkan yaitu kompetensi pedagogik, kepribadian, sosial dan professional. Peneliti menyarankan agar penilaian kinerja guru jangan hanya formalitas untuk melengkapi bahan administrasi karena bila melakukan penilaian hanya formalitas maka hasil yang dicapai untuk meningkatkan pendidikan secara utuh tidak akan pernah tercapai. Dimana guru diharapkan terus berkembang meningkatkan kompetensi pedagogik, kompetensi profesional, kompetensi sosial, kompetensi kepribadian.

\section{Hubungan kualifikasi akademik guru dengan hasil belajar siswa pada SMA Negeri di Kota Jambi}

Hasil Penelitian menunjukkan bahwa dari 9 mata pelajaran responden yang Tidak Berkualifikasi, sebanyak 1 (11,11\%) responden dengan hasil belajar Kurang Baik, sebanyak 4 (44,44 \%) Berkualifikasi dengan hasil belajar Kurang Baik, sebanyak $4(44,44 \%)$ responden Berkualifikasi dengan hasil belajar Cukup. Hasil uji statistik diperoleh nilai $p$-value $=0,1000$ maka tidak terdapat hubungan yang signifikan antara kualifikasi akademik guru dengan hasil belajar siswa pada SMA Negeri di Kota Jambi Tahun Ajaran 2018-2019.

Berdasarkan hasil penelitian diketahui bahwa umumnya responden termasuk dalam kategori guru yang berkualifikasi, tetapi tidak dengan hasil belajar siswa yaitu dengan rendahnya nilai UNBK siswa. Seharusnya dengan tingginya kualifikasi akademik guru diharapkan hasil belajar siswa baik pula. Hal tersebut diduga terdapat faktor lain yang menyebabkan hasil belajar siswa rendah, yaitu salah satu indikator tolak ukur keberhasilan suatu lembaga pendidikan dalam menghasilkan lulusan yang berkualitas melalui hasil belajar yang dicapai atau nilai yang diperoleh pada setiap mata pelajaran yang disajikan. Faktor-faktor yang dapat mempengaruhi faktor internal (dari dalam diri siswa) maupun faktor eksternal 
(dari luar diri siswa), di antaranya fasilitas belajar, partisipasi orang tua, kebiasaan belajar, aktivitas belajar, motivasi berprestasi, serta sikap terhadap sekolah.

\section{Hubungan kinerja guru dengan hasil belajar siswa pada SMA Negeri di Kota Jambi}

Hasil Penelitian menunjukkan bahwa dari 9 mata pelajaran responden yang memiliki kinerja guru Tidak Baik, sebanyak $1(11,11 \%)$ responden hasil belajar kurang baik, sebanyak 4 ( 44,44\%) memiliki kinerja guru Sangat Baik dengan hasil belajar Kurang Baik, sebanyak $4(44,44)$ responden kinerja guru Sangat Baik baik dengan hasil belajar Cukup Baik. Hasil uji statistik diperoleh nilai $p$-value $=0,1000$ maka tidak terdapat hubungan yang signifikan antara kinerja guru dengan hasil belajar siswa pada SMA Negeri di Kota Jambi Tahun ajaran 2018-2019. Berdasarkan hasil penelitian diketahui bahwa umumnya responden memiliki kinerja guru Sangat Baik, tetapi tidak dengan hasil belajar siswa Kurang Baik yaitu dengan rendahnya nilai UNBK siswa.

Dari hasil penelitian yang telah Peneliti lakukan diketahui tidak terdapat hubungan antara kinerja guru dengan hasil belajar siswa. Hal ini disebabkan variabel $\mathrm{Y}$ yaitu hasil belajar berdasarkan hasil nilai Ujian Nasional, dimana tingkat kesulitan soal yang standarisasi nilainya ditentukan oleh pusat. Dengan adanya Ujian Nasional berarti asumsinya semua siswa mampu mencapai standar akademik yang telah ditentukan oleh pusat. Semua siswa diperlakukan seolah intelektual, daya serap, muatan akademis, latar belakang ekonomi, dan kondisi keluarganya sama. Belum lagi keberagaman fasilitas sarana dan prasarana sekolah tempat mereka belajar, akses terhadap teknologi dan informasi, maupun kemampuan kinerja guru ditempat sekolah mereka. Siswa dengan latar belakang ekonomi mampu mendapatkan kesempatan untuk mendapatkan fasilitas belajar yang baik sehingga peluang lebih besar untuk hasil belajar baik pula. Namun hasil belajar yang baik tidak dengan mudah diperoleh oleh siswa dengan latar belakang ekonomi kebawah. Oleh karena standar yang sama dibuat oleh pemerintah pusat dengan keberagaman kondisi siswa dapat mempengaruhi hasil belajar siswa.

Hal tersebut didukung dalam jurnal Hidayah (2013), bahwa ujian yang distandarkan sering menjadi pemicu ketika sistem yang dibangun belum memenuhi syarat untuk menjadikan ujian tersebut sebagai indikator yang dapat diukur. Bahkan di negara maju yang secara sistem telah terbangun dengan baik seperti Amerika Serikat, pemberlakuan ujian yang distandarkan menuai banyak pertentangan dan dianggap tidak adil, mengabaikan keragaman siswa, serta merugikan minoritas dari ekonomi kelas bawah yang mempunyai keterbatasan untuk mendapatkan sumbersumber belajar. Dampak ujian yang distandarkan menurut Lomax dalam jurnal Hidayah (2013), menuliskan tiga dampak serius ujian yang distandarkan dan tersentralisasi yaitu :

a. Berkurangnya waktu untuk pengajaran,

b. Diabaikannya materi kurikulum yang tidak diujikan, dan

c. Meningkatnya pemakaian materi persiapan yang mirip dengan tes

\section{Hubungan kualifikasi akademik guru dengan kinerja guru d pada SMA Negeri di Kota Jambi}

Hasil penelitian menunjukkan bahwa dari total 30 responden yang dikategorikan Tidak Berkualifikasi berjumlah $1 \quad(3,3 \%)$ responden dengan kinerja guru Tidak Baik, sebanyak $29(96,7 \%)$ responden termasuk dalam kategori Berkualifikasi dengan 
Kinerja Guru Sangat Baik. Hasil uji statistik diperoleh nilai $p$-value $=0,008$ maka $\mathrm{H}_{\mathrm{a}}$ diterima dan $\mathrm{H}_{0}$ ditolak. Sehingga dapat disimpulkan terdapat hubungan yang signifikan antara kualifikasi akademik guru dengan kinerja guru pada SMA Negeri di Kota Jambi Tahun ajaran 2018-2019.

Berdasarkan hasil penelitian menunjukkan bahwa terdapat hubungan yang signifikan antara kualifikasi akademik guru dengan kinerja guru, dengan hasil penelitian guru berkualifikasi dan memiliki kinerja sangat baik sebanyak $96,7 \%$ dan guru tidak berkualifikasi dan kinerja kurang baik sebanyak 3,3\%, maka peneliti dapat menarik kesimpulan bahwa semakin tinggi kualifikasi akademik guru maka kinerjanya semakin meningkat dan profesional.

\section{Hubungan kualifikasi akademik dan kinerja guru dengan hasil belajar siswa pada SMA Negeri di Kota Jambi}

Berdasarkan hasil penelitian diketahui bahwa $1 \quad(3,3 \%)$ responden kualifikasi akademik guru termasuk dalam kategori Tidak Berkualifikasi dan sebanyak 29 $(96,7 \%)$ responden kualifikasi akademik guru termasuk dalam kategori Berkualifikasi. Sebanyak $1(3,3 \%)$ responden kinerja guru Tidak Baik dan sebanyak 29 (96,7\%) responden kinerja gurunya Sangat baik, 9 mata pelajaran responden 5 mata pelajaran $(56,6 \%)$ mata pelajaran resonden memiliki hasil belajar siswa kurang baik dan 4 mata pelajaran $(44,4 \%)$ memiliki hasil belajar siswa termasuk dalam kategori Cukup.

Berdasarkan hasil penelitian diketahui bahwa tidak terdapat hubungan yang signifikan antara kualifikasi akademik dan kinerja guru dengan hasil belajar siswa. di SMA Negeri di Kota Jambi Tahun Ajaran 2018-2019. Diketahui kualifikasi guru termasuk dalam kategori Berkualifikasi dan kinerja guru termasuk dalam kategori Sangat
Baik. Namun mengapa hasil belajar siswa yang dilihat dari nilai UNBK belum memuaskan. Hal ini diduga banyak faktor yang mempengaruhinya. Pertama, berhasil tidaknya siswa dalam pencapaian hasil belajar yaitu berasal dari dalam diri siswa itu sendiri. Hal ini didukung oleh Syah dalam Priansa dan Setiani (2018), yang menyatakan bahwa hasil belajar dapat dipengaruhi oleh faktor internal (keadaan/kondisi jasmani dan rohani dalam diri siswa) dan faktor eksternal (kondisi lingkungan) serta faktor pendekatan belajar.

\section{SIMPULAN}

Dari 30 responden guru dan 9 hasil nilai mata pelajaran yang termasuk dalam UNBK diperoleh $96,7 \%$ responden memiliki kualifikasi akademik Berkualifikasi, kinerja guru Sangat Baik yaitu 96,7 \%, dengan hasil belajar termasuk dalam kategori Cukup yaitu $44,44 \%$ pada Sekolah Menengah Atas Negeri di Kota Jambi Tahun Ajaran 20182019. Hubungan variabel bebas (XI) kualifikasi akademik guru dengan variabel terikat (Y) hasil belajar siswa yaitu tidak terdapat hubungan yang signifikan antara kualifikasi akademik guru dengan hasil belajar siswa di Sekolah Menengah Atas Negeri di Kota Jambi Tahun Ajaran 20182019. Hubungan variabel bebas (X2) kinerja guru dengan variabel terikat (Y) hasil belajar siswa yaitu tidak terdapat hubungan yang signifikan antara kinerja guru dengan hasil belajar siswa di Sekolah Menengah Atas Kota Jambi Tahun Ajaran 2018-2019. Hubungan variabel bebas (X1) kualifikasi akademik guru dan variabel bebas (X2) kinerja guru yaitu terdapat hubungan yang signifikan antara kualifikasi akademik guru dengan kinerja guru di Sekolah Menengah Atas Kota Jambi Tahun 2018-2019. Hubungan variabel bebas (XI) kualifikasi akademik dan variabel bebas (X2) kinerja 
guru dengan variabel terikat (Y) hasil belajar siswa yaitu tidak terdapat hubungan yang signifikan antara kualifikasi akademik dan kinerja guru dengan hasil belajar siswa di Sekolah Menengah Atas Negeri di Kota Jambi Tahun Ajaran 2018-2019.

\section{REFERENSI}

Arikunto, S. 2013. Prosedur Penelitian. Jakarta: Rineka Cipta.

Dermawati. 2013. Penilaian Angka Kredit Guru. Jakarta: Bumi Aksara.

Hamalik, O. 2010. Kurikulum dan Pembelajaran. Jakarta: Bumi Aksara.

Hidayat, A dan Machali, I. 2010. Pengelolaan Pendidikan. Bandung: Pustaka Educa.

Priansa, DJ. 2018. Kinerja Dan Profesionalisme Guru. Bandung: Alfabeta.

Sugiyono. 2009. Metode Penelitian Kuantitatif Kualitatif Dan $R \& D$. Bandung: Alfabeta.

- 2010. Metode Penelitian Pendidikan. Bandung: Alfabeta.

Undang-Undang Nomor 14 Tahun 2005. Tentang Guru dan Dosen Pada Pasal 8.

Undang-undang Republik Indonesia Nomor 20 tahun 2003. Tentang Sistem Pendidikan Nasional.

Peraturan Pemerintah Nomor 19 Tahun 2005.

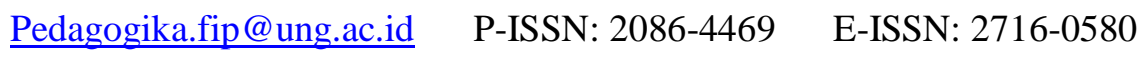

Hidayah, N. 2013. Penelitian Ujian Nasional dalam Perspektif Kebijakan Publik. Jurnal pencerahan volume 7 , nomor 1 maret 2013 hal 35-40. 